\title{
Response to Judith Anderson's Comments on Low, Alexander, and Noonan (1987)
}

\author{
Bobbı S. Low, Richard D. Alexander, \\ and K. M. Noonan \\ School of Natural Resources, Unuersitr of Michigan $B S L$, Elolution \\ and Human Behailol Program, Unuersin of Michugan ( $B S L, R D A)$. \\ and The Museum of Zoologi. Unuersut of Michigan (RDA $K M N$ ) \\ tinn Aibor Michigan
}

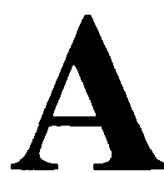

nderson develops six arguments that she believes counter those of Low et al (1987) in regard to sexual selection and the possibility that fat deposits on the hips, breasts, and buttocks of human females are deceptive We think her arguments cannot be sustained

1 She argues that sexual selection has not been an important influence on either the behavior or the phy'siology and morphology' of human females, citıng Gee (1982) that in nontechnological cultures most marriages are arranged. and in most cultures $95 \%$ of the women marry Items of importance in sexual selection, however, are not evolved simply to attract mates, but also to attract the best mates Wherever males vary significantly in quality (Including especially, their promıse of parental care-of all forms), females potentially can gain immensely by attractıng the interest of superior males (see, e g. Lou 1979) Even in societıes with arranged marriages, variations occur in the desirability of females. as is evidenced by differences in ages of marriage and bride price (e $\mathrm{g}$. Borgerhoff Mulder, 1988) Our hypothesıs implies that across history, females have invested a great deal in mate attraction, and the principal reason is that human males do indeed vary dramatically in quality There is evidence that women or their families in nontechnological societies exert considerable effort into the attraction of pow'erful or resource-rich males re $\mathrm{g}$. Flinn and Low 1986)

2 She believes that evidence of variations in what human males apparently find attractive denies that some attributes in uomen are viewed as desirable by men generally. and that the fact that some of human males"

Recelved Februar 81988 revised February 81988

Address reprint requests to Bobbi S Lou Ph D School of Natural Resources Evolution and Human Behavior Universits of Michigan Ann Arbor MI 48109 
interests in female attributes are learned denies that evolution and sevual selection have been involved We are aware of cultural differences in male preference and argue that these variations in preference and the observable responses to such preferences constitute powerful evidence that sexual selection does act on human females as well as males We do not think that partıcular cultural traditıons (e $g$. Chınese bound feet) or temporar fads (e $g$. flappers) deny the existence of traits of general interest. and we doubt that anyone has eliminated the possibility that there are some attributes of the human female that virtually all men find attractive (e g. Buss 1987) The traits likel, to be broadly appreciated are those reflecting health. high reproductuve value, and receptiveness (Lou 1978)

On the second point Anderson seems to be confusing proximate and ultumate causes surelt it is no longer necessart to emphasize that the capacil to learn is evolved and that what is learned is not random ie g Alexander 1979 Cosmides and Toobs 1987)

3 She argues that there is no correlation between breast size outside lactation and success in lactation The book she cites however is designed to promote breastfeeding iniolves a modern technological societt, and presents no data but only an assertion that size does not matter In fact the hypothetical illustration given in Minchin (1985, p 112) supports our hrpothesis that fat on the breasts may be deceptive. showing a small nonfatty breast compared to a large breast with little glandular tissue and much fat As we noted, that breast size is currently unrelated to lactation success in technological societies (with supplemental feeding) is irrelevant to the hypotheses that breast size was important in evolutionary history and that patterns of breast stze and lactation frequency might co-sary cross-culturally Anderson in inconsistent in using a modern society to make her point " hile previously arguing (in connection with male preferences) that modern society cannot be used as a criterion

Breastfeeding fallure $w$ hile commonls due to insufficient information. lack of confidence, etc may also occur because of insufficient glandular development of the breast, and uch insufficiencs mas be heritable (Niefert et al 1985) this again argues that bredst development and size due to mammary tissue have not been irrelesant to success that large breasts due to fat are deceptuse and that sexual selection is likels to have operated

She argues that breast size cannot indicate storage capacit because milk production and storage are antagonistic functions in humans citıng evidence that storage of milk for more than a feu hours leads to a reduction in milk production These two functions cannot houever be adversarial at base unless nursing is continuous We would rather describe this relationship as indicatıng that falure to use milk eventually results in low ered production of it The data in the papers eited bs Anderson do not suggest that larger breasts eannot both produce and store more milk as we would suggest. except when the breast is large by virtue of fat deposits rather than glandular and storage tissues ts we noted the point at which storage of 
milk w'ithout use inhibits further production $v$ aries among species, depending on the pattern of lactation frequency We suggested that it may vary among societies. depending on the history of lactational frequency patterns

4 She believes that evidence that the birthing-functional aspects of the female pelvis cannot accurately be determined externally, and that the Ilac crests yıeld a false pelvis" effect, deny our hypothesis that the human female may have evolved to give the appearance of a wider pelvis than is actually the case Both points, how'ever, may support the deception argument The more difficult is accurate assessment. the more difficult it is to detect deception She also believes that difficulty in birth ow ing to large cephalic dimensions is largely owing to unfavorable birth postures required in modern hospitals Needed here is a comparison of cephalic dimensions relatıve to maternal sıze and a compilation of informatıon (currently lackıng) about head size and birthıng difficulties in nontechnological societıes

5 She argues that females could not gain reproductively by giv ing false impressions about pelvic width We have already countered this argument b) notıng that what males favor and $w$ hat is best for females mav be different Her argument however requires that females deceıve males while heepıng their pelvises narrow er than would be to their ow $n$ advantage, our argument involves males favoring wider pelvises than would be advantageous to females Further wide hips. whether or not they ever made birth easier. could increase in frequency if favored by males for any trat to be favored through sexual selection. It need not render any adiantage to the possessors of the trait, other than being favored by the choosing sex (Fisher 1958)

6 She presents four hypotheses as alternative to ours that wide hips evolved to assist females in carrying babies, that fat evolved to insulate women's breasts and buttocks. that breast fat is an adaptation for makıng the breast large and soft enough so as to be convenient for an infant to reach," and that the function of breast fat is contribution to a particular hormonal environment She indicates that mosi" of these hy potheses are easily falsifiable " but makes no effort to falsıfy' them First, none of these hy potheses excludes ours and sexual selection does not seem to be excluded in any case For example. Hottentot women carry their babies on their prominent buttocks, and men evidently have used buttock size as a criterion in sexual selection (e g Daruin 1871. II 345) Similarly wide hips could easily be selected on several bases, including sexual selection

Second the hy pothesis that breast fat evolved to insulate the mammart ussue, and that buttock fat functions to insulate the posteriors of women sitting on the ground is testable Breast size due to fat and fat deposits on the buttocks should increase as cold stress increases We specifically argued however, that fat on the buttocks is not deceptive If sexual selection were not insolved men living in cold climates should also have extra fat on the buttocks In fact steatopygla is most pronounced in women in a subtropical area, and there is evidence that sexual selection has been powerful even in opposition to selection on ability to move 
Thırd, she suggests that breast fat functions to make the breast avalable to infants who need a breast that will hang conveniently as it rides on its mother s hips" If fat were advantageous in producing elongate, pendulous breasts then such breasts should be unusually fatty we know of no ev'idence suggesting this

Finally fat mat contribute to a hormonal environment but it is a confusion to suggest that it evolved in breasts because some particular hormonal enutionment was important Not only are provmate and ultumate mechanısms being mixed (again) as in Masia-Lees et al (1986) criticised in our original paper but if this is its function one has to wonder why extensile elaboration of breast fat seems to have evolved only in humans

Some of Anderson s arguments are also critically reviewed br Caro 11987) who cites additional reterences Caro misstates the original deception hy pothesis of Low 11979 cited but not referenced but nevertheless falls to dismiss the hipothesis that fatty breasts mat be decepuse

\section{REFERENCES}

Hexander R D Dammalmand Human tflatrs Seattle Unisersits of Washington Press 1979

tnderion Judith L Comments on Low B S R D tlexander and K $\mathbf{M}$ Noonan Ethologi and Sachoholong 9 (0)-00 1488

Borgerhott Mulder $\mathbf{M}$ Kipigıs bridewealth pasments In Human reproductut behailor L L Betzıg $\mathbf{M}$ Borgerhott Mulder and $\mathbf{P}$ Turke IEds , Cambridge Cambndge Universit Press 1988

Bus, D Ses differences in human mate selection sritena in evolutionars perspective In Kreb, eds Sercobiologe and Psichologi Issues Idtas and Findings C Drautord $M$ Smith and D Krebs IEds I Hillsdale N J Erlbaum 1987

Caro T M Human breasts unsupported hypotheses revieued Human Eidutum 2 271-28? $198^{7}$

Cosmider L and Toubs J From erolution to behavior evolutionars pstchologi as the miss ing link In The Latest an the Be'st Essass on Eadutum and Optumalan J Dupre led, Cambridge Mass MIT Pres, 1987

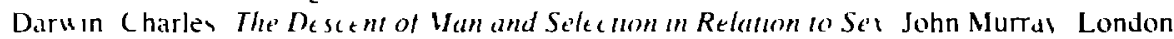
$\left|x^{7}\right|$ Fassimile Edition (ulture et Cisilisation Brussels 1969

Fisher R I The Gene'lual Then of Vatural Selectum New York Dover 1958

Flinn $M 1$ and Low Bobbi $S$ Resource distribution social competition and mating pattern. in human societies In Ecological troects of Social Elolution D I Rubenstein and R II W'rangham ied, I Princecon Princeton LInis Press 1986

Gee E M T Marrage in nineteenth centurs Canada Canad Re'b $S$ te and thihrop $19311-$ $32514 \times 2$

Low Bobhi S tlesander R D and Noonan K M Human hips breasts and butlochs Is

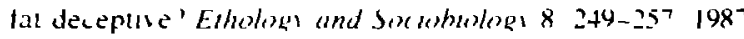

- Sevual velection and human ornamentation In Eiolutuman Theon and Human Soctal () gam-atum N Chagnon and $W$ Ironsleds I North Siltuate Dusburs Press 1979 $\mathrm{pp}+\mathrm{h}:-48^{7}$

Masta-Lees F E Relethtord J H and Sorger T Evolutionart perspectues on permanent hreast enlargement in human temales fmer finthrop $88 \quad 423-4291986$

Minchin M Breavlletdine V/atle's Sidnes flma and George fllen and l'nu in 1985

Nietert Marianne R Seacal Jor M and Jobe Willam E Lactation fallure due to insufficient glandular development of the hreas Pediatric, 76 823-828 1985 